\title{
The Relationship between Organizational Identity and Academic Optimism with the Mediating Role of Organizational Image in the Islamic Schools in Tehran
}

\author{
-Omid Mehni*1 -Mansoureh Mashayekhi ${ }^{2}$-Soheila Mokhtari ${ }^{3}$-Ayoub Faizy ${ }^{4}$-Abbas Tavan ${ }^{5}$
}

- Objective: The present study aims to investigate the mediating role of organizational image in the relationship between organizational identity and academic optimism in Islamic schools in Tehran.

- Method: The study is applied in terms of purpose and descriptive and correlational in terms of method. The statistical population includes all of 270 teachers of Islamic primary schools in Tehran. The sample size was 159 using Krejcie and Morgan (1970) table. Simple random sampling method was used to select the statistical sample. In order to collect the data and information required in this study, the Academic Optimism Questionnaire of Beard, (and Hoy, and Woolfolk Hoy, 2010), the Organizational Identification Questionnaire of Mael and Ashforth (1992) and the researcher-made organizational image questionnaire were used. The reliability of them was $0.85,0.81$ and 0.79 , respectively. Pearson correlation coefficient and structural equation modeling were used to analyze the data.

- Findings: The Findings showed that there was a relationship between organizational identity and academic optimism, between organizational identity and organizational image, and between organizational image and academic optimism. Furthermore, the findings showed that there was a relationship between organizational identity by the mediating role of organizational image, and academic optimism.

- Conclusion: Academic optimism is one of the signs of success in schools, and what will improve this important component in Islamic schools is paying attention to the organizational identity and organizational image of Islamic schools. The beneficiaries' improper understanding of the organizational identity and organizational image of Islamic schools and its capacities will affect the quality of education and the overall performance of these schools.

Keywords: organizational image, organizational identity, academic optimism, Islamic schools.

- Citation: Omid Mehni, Mansoureh Mashayekhi, Soheila Mokhtari, Ayoub Faizy, Abbas Tavan. (2021). The Relationship between Organizational Identity and Academic Optimism with the Mediating Role of Organizational Image in the Islamic Schools in Tehran, Applied Issues in Islamic Education, 6(3): 103-122.

Received: 2021/05/14 Accepted: 2021/11/13

1. Corresponding Author: PhD Student in Educational Administration, Department of Educational Administration, Faculty of Management, Kharazmi University, Tehran, Iran.

E-mail: OMehni@Chmail.ir (iD) 0000-0001-8138-1260

2. PhD Student in Educational Administration, Department of Educational Administration, Faculty of Management, Kharazmi University, Tehran, Iran.

E-mail: mansourem91@gmail.com (iD) 0000-0001-8901-2785

3. PhD Student in Educational Administration, Department of Educational Administration, Faculty of Management, Kharazmi University, Tehran, Iran.

E-mail: s_mokhtari67@yahoo.com (iD 0000-0003-2136-0008

4. PhD Student in Educational Administration, Department of Educational Administration, Faculty of Management, Kharazmi University, Tehran, Iran.

E-mail: faizy.edu@gmail.com (D) 0000-0002-6758-419X

5. Assistant Professor Islamic Philosophy, Department of Philosophy, Faculty of Literature and Humanities, Shahid Bahonar University, Kerman, Iran.

E-mail: abbastavan@yahoo.com (iD 0000-0002-1428-0272 






Q

ه هدف: يزوهش حاضر با هدف بررســـى نقش ميانجى تصوير سازمانى در رابطه بين هويت




















H مدل سازى معادلات ساختارى استفاده شد.

* نويسنده مسئول: دانشجوى دكترى مديريت آموزشى، كروه مديريت آموزشى، دانشكده مديريت، دانشعاه خوارزمى، تهران، ايران. E-mail: OMehni@Chmail.ir (iD) 0000-0001-8138-1260

$$
\text { *** دانشجوى دكترى مديريت آموزشى، كروه مديريت آموزشى، دانشكده مديريت، دانشخاه خوارزمى، تهران، ايران. }
$$

E-mail: Mansourem91@Gmail.com (iD) 0000-0001-8901-2785

$$
\text { *** دانشجوى دكترى مديريت آموزشى، كروه مديريت آموزشى،دانشكده مديريت، دانشعاه خوارزمى، تهران، ايران. }
$$

E-mail: S_Mokhtari67@Yahoo.com (iD) 0000-0003-2136-0008

*** دانشجوى دكترى مديريت آموزشى، كروه مديريت آموزشى، دانشكده مديريت، دانشگاه خوارزمى، تهران، ايران.

E-mail: Faizy.edu@Gmail.com (iD) 0000-0002-6758-419X

*** استاديار فلسفه اسلامى، گروه فلسفه، دانشكده ادبيات و علوم انسانى، دانشعاه شهيد باهنر، كرمان، ايران.

E-mail: Abbastavan@Yahoo.com (iD) 0000-0002-1428-0272 















مدرسه تأثير كذار خواهد بورسن



\section{مغندم}

آموزش و يرورش بهعنوان يك نهاد فرهنگیى اجتماعى، نقش اساسى و سرنوشتساز در تربيت نيروى انســانى و توليد سرمايه اجتماعى و فرهنكَى و در فرآيند رشد و تعالى


امروز به نظاره نشســت (ضربى، امير كبيــرى و ربيعى مندجين، . · I ). در بين عوامل درونى نهاد مهلم آموزش و يرورش، مدرســهـ نقش تعيين كنـندهاى در موفقيت يا شكست برنامههاى اين نهاد مهمم دارد و از اينرو مدرسه بهعنوان نهاد اصلى آموزش رسمى و ركن اصلى بقاى تعليم و تربيت محسوب مىشود (بهراميان، نادى و كريمى، 19 ب |). با توجه به جايعًاه مهرم نهاد مدرســه، در طول دو دهه اول قرن بيستويكم، سؤالات مربـــوط به نقش مدارس در جوامع بهعنـــوان موضوعات اصلى براى مقابله با جالشهاى آينده مطرح شده است. مدارس بهعنوان نهادهاى مهمى در جوامع كه دانش آفرينى را در بين نسل جوان ايجاد مى كنند و بهعنوان سازوكارى براى توسعه شهروندان جوامع تعريف مىشوند (Erstad, Mino \& Rivera-Vargas, 2021). اهميت و تأثير خذارى مدرسه در توسعه اقتصادى، فرهنگیى، اجتماعى و سياسى موجب شده است جوامع مختلف نسبت به سياست گذارى و برنامهريزى براى شكلدهى به مدارس اقدام كنند. از طرفى دين اسلام مقولهٔ تعليم و تربيت را از عوامل رسيدن فرد به تكامل مىداند و وجود آيات و روايات در اين زمينه باعث شــد تا جهان اسلام به تعليهم و تربيت اسلامى نگاهى ويثره داشته باشد؛ 
رابطه بين هويت سازمانى و خوش بينى تحصيلى بانقش ميانجى

تصوير سازمانى در مدارس اسلامى شهر سيت تهران



بهَگونهاى كه اصل تعليم و تربيت مورد توجه حكومتهاى مختلف اســلامى قرار گرفت






















فزايندهاى مورد تقاضا هستند، زيرا اين مدارس توقعات والدين براى تحصيلات دينى و آموزش عمومى فرزندان را ياســخ مى دهند (Misbah \& Sulaeman, Bakhri, 2019).






Susylowati, Sumarlam, Abdullah \& Marmanto, 2019) به موقعيت و جايعاه اجتماعى و آموزشــى مدارس اســلامى، بررســى عوامل زمينهساز موفقيت اين مدارس بسيار مهم خواهد بوديت

در راستاى اهميت جايكاه مدارس، يزوهشهار مهاى متعددى در در زمينه عوامل زمينهساز موفقيت اين نهاد مهم صورت كرفته اسـت. در اين خصوص و در سالهاى اخير مفاهيم




قرار كرفتـه اسـت ( Moghtadaie \& Hoveida, 2015, Sezgin \& Erdogan, 2015, (Makvandi, Naderi, Makvandi, Pasha \& Ehteshamzadeh, 2018 
شـــن اين مفاهيه، نقش و جايعاه كادر آموزشــى و در رأس ايشان معلمان در موفقيت مدرســـه مىباشد. در نظام آموزشــى بهطور كل، و مدرسه بلهطور خاص، معلمان هسته اصلى بهشــمار مىروند و ويزز گى هاى شخصيتى و تخصصى آنها بر اثربخشى كل مدرسه اثر مى حذارد. از اينرو است كه معلمان بهدليل در گيرى مستقيمى در فعاليتهاى آموزشى،

نقشى اساسى در تحقق اهداف مدارس دارند (Utami \& Vioreza, 2021).




حوزه باورهاى معلم موجب شــد تا هوى، تارتر و وولفولى هوى' (9 . . ب) براى نخستين بار مفهوم جديدى را با عنوان خوشبينى تحصيلى به عرصه روانشناسى تربيتى معرفى مؤى


كـــه مى تواند با تأكيد بر موضوعات علمى و يادكيرى، با اعتماد به والدين و دانشآموزان به همكارى در فرايند و با اعتقاد به توانايى خود در عملكرد علمى دانشآموزان تغييرى ايجاد كند، بر مشكلات غلبه كرده و با مقاومت و وشتكار در برابر شكست واكنش نشان

دهد (Eren, 2012).

تعريف مفهومى خوشبينى تحصيلى نشاندهنده آن است كه خوشبينى تحصيلى هم سازهاى جمعى است و هم فردى. اين مفهوم شامل ابعاد شناختى، عاطفى و رفتارى اســت كه از تعامل بين حس كارآمدى جمعى ؟ اعتماد دانشآموزان و والدينَّ و تأكيد تحصيلى بَ بهعنوان بخشى از سلامت ســازمانى مدارس ايجاد شده است. اين سه مؤلفه







خوشبينى تحصيلى تأثير نيرومندى بر اهداف و فعاليتهاى آموزشى معلمان مدارس مى كذارد (Sezgin \& Erdogan, 2015)؛ و از اينرو Hsieh, Yen \& Kuan (2014) بيان مى دارند كه از خوشبينى تحصيلى مى توان براى توصيف موفقيت يك مدرسه استفاده كرد. لذا با توجه به اهميت بســيار زياد خوشبينى تحصيلى، ضرورى اســت كه عوامل

1. Hoy, Tarter \& Woolfolk Hoy

2. Social Self-Efficacy

3. Faculty Trust in Students and Parents

4. Academic Emphasis 
مؤثر بر آن مورد توجه قرار كيرد. در اين راســتا Wu \& Sheu (2015) بيان مىدارند كه بيشــتر عوامل شناسايى شده مؤثر بر خوشبينى تحصيلى مؤلفههاى مربوط به مفاهيم روانشناختى سازمانى هستند. در ميان مفاهيم مهمر روانشناختى سازمانى و يكى از مهمترين موضوعات در سالهاى

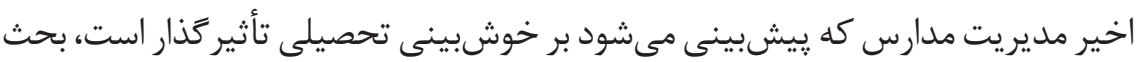






تأثير مى كذارد (Boz \& Saylik, 2021). در ســالهاى اخير هويت مزيتى رقابتى براى ســازمانها محسوب مىشود. هويت
















مورد سازمانهاى خود فكر مى كنند ارتباط دارد (Yilmaz \& Turgut, 2016). در واقع،








خود را از طريق توضيح دادن درباره اهداف ســازمان، معانى رفتارها و اقدامات سازمان،


ســازمان خود بيان مى كنند (Levin, Lopez Damian, Martin \& Vazquez, 2018).




اعتقادات اسلامى شــكل دهندهى اصلى هويت افراد در سازمان است. اين امر موجبات موفقيت ســازمانى را ايجاد خواهد كرد، زيرا كاركنانى كه ارزش ها و اهداف سازمانهاى


موفقيت سازمانى انجام مىدهند. از اينرو است كه هر سازمانى نياز به داشتن هويت قوى منحصر به خود دارد (Eksi, Ozgenel \& Demirci, 2020). يزوهشهاى انجام گرفته در زمينه هويت سازمانى، علاوه بر اينكه اهميت آن را نشان مىدهد، گوياى اين مطلب نيز اســت هويتيابى قوى به سطح بيشترى از رضايت شغلى، رفتارهاى فرانقش و رفتارهاى مشاركتى افراد در سازمان منجر مىشود كه در نتيجه به كاهش احساس قصد ترك شغل و غيبت سازمانى و افزايش اشتياق و رضايت از كار منجر مىشود كه به تبع آن رفتارهاى مثبت نسبت به مراجعين سازمانى افزايش مىيابد كه اين خود بر محيط خارجى سازمان نيز تأثير گذار است (امين بيدختى، جعفرى و مرادى مقدم، هوس ().


حذارد، اما اين اثر غير مستقيم است و از طريق تغيير ساختار درونى مدرسه، فرآيندها و مأموريتهاى مدرســـه كه به صورت مستقيم به عملكرد معلمان ارتباط دارد، رخ مى دهد و از اينرو امروزه تصوير ســازمانى يكى عامل كليدى براى موفقيت سازمانهاى آموزشى


تصويـــر خود براى جذب اعضاى جديد تكيه مى كنند، جرا كه براى محيط رقابتى امروز، تصوير ســازمانى و داشــتن برند مناســب در محيط رقابتى آموزش بســيار مهرم است كآ (Erdogmuş \& Ergun, 2016)؛ زيرا اين امر مى تواند سازمان را رهبرى كند تا موقعيت و مزيت يايدار رابراى آن ايجاد كند (Hemsley-Brown, 2016 \& Nguyen, Melewar)، و از اينرو است كه بسيارى از سازمانهاى آموزشى توانايى ايجاد تصوير سازمانى مناسب را در بازار رقابتى مفيد مىدانند (Rauschnabel, Krey, Babin \& Ivens, 2016). تصوير و شهرت يك سازمان آموزشى در نزد ذينفعان خود، عامل بسيار مهمى براى موفقيت آن سازمان خواهد بود (Heinberg, Ozkaya \& Taube, 2018). بنابراين، ايجاد اين تصوير براى ســازمانهاى آموزشى بســـار مهـم است، جرا كه مدارسى كه جهت بقا و فعاليت به شدت وابســته به محيط اطراف خود هستند، تصوير خارجى كه مخاطبان




مىتواند اسـتراترى خاصى را از سوى آن مدرسه ايجاد كند (Hilman \& Siam, 2014).

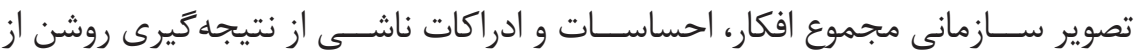

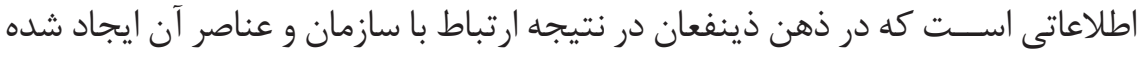
است (Kucuksuleymanoglu, 2015). در واقع، مىتوان كفت تصوير سازمان، از ارزيابى

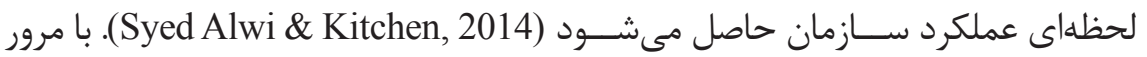
ادبيات و مبانى نظرى موجود در اين حيطه در مجموع مىتوان كَفت، تصوير شــيوهاى


برجسته مىسازند و نيز نشاندهنده شخصيت هر سازمان آموزشى است و سمت و سوى آنى

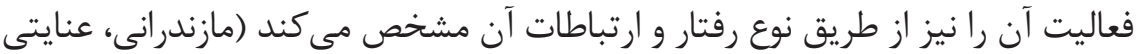

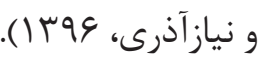
ايجاد تصويرى تأثير گذار و مثبت، براى سازمانها از اهميت بسيارى برخوردار است،

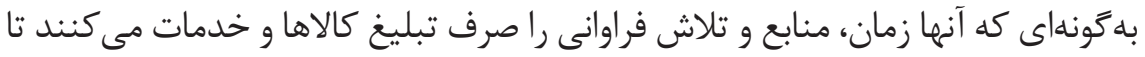



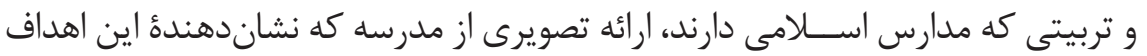
باشد داراى اهميت فراوانى است. به عبارتى بيان اهداف روش، راهبردها، بيان ويزگگ هاى

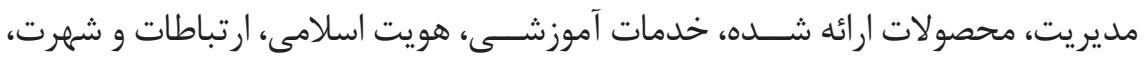

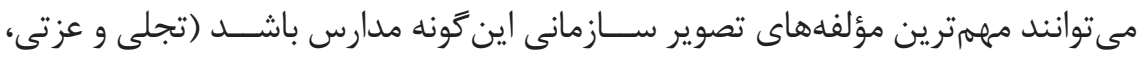

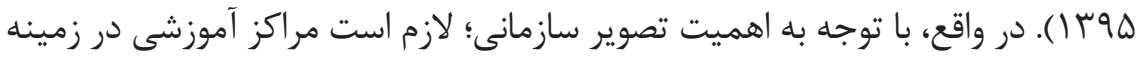

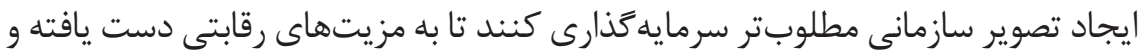

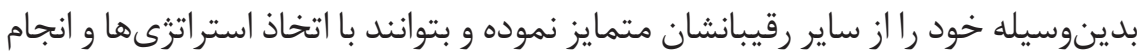

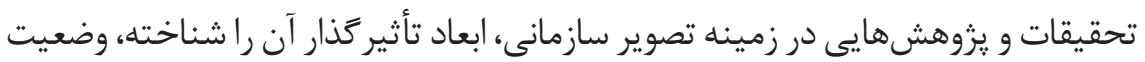

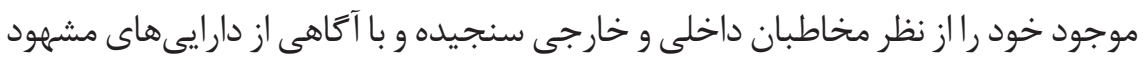

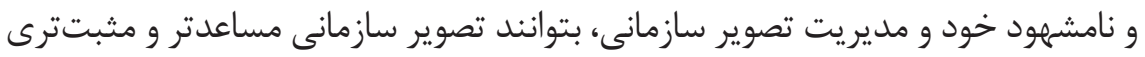
در اذهان مردم و مخاطبين به وجود آورند (دازدارى، عنايتى و ضامنى، وجس ا ). همان كَنه كه در خصوص مؤلفههاى مدنظر يزوهش حاضر بيان گَرديد؛ مى توان كَفت

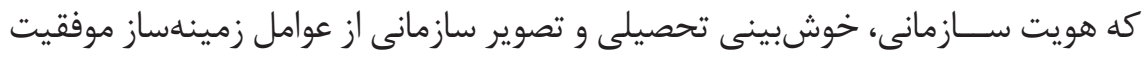




كشور ما كمتر به عوامل زمينهساز موفقيت اين مدارس يرداختهاند و يرسش هاى زيادى در اين زمينه بدون ياســخ مانده است. لذا انجام اين يزوهش از اين لحاظ داراى اهميت دارد كه مديران مدارس اســلامى و مديران ردههاى بالاتر در سازمان آموزش و يرورش


بهبود فرايندهاى ياددهى و يادگيرى و موفقيت هر جه بيشتر اين مدارس تسهيل شود. لذا بر اساس آنجه كه بيان گرديد، با توجه به اهميت نقش خوشبينى تحصيلى در تحقق اهداف سازمانى و از طرفى ضرورت شناسايى عوامل مؤثر بر اين مؤلفه مهلم و آنجه را كه

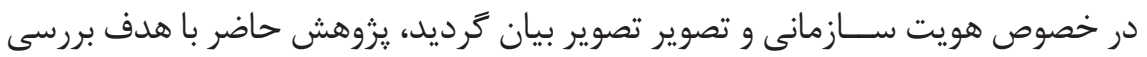
نقش ميانجى تصوير ســازمانى در رابطه بين هويت سازمانى و خوشبينى تحصيلى در مدارس اسلامى شهر تهران انجام مى گيرد.



هويت سازمانى



شكل ا. مدل مفهومى يزوهش

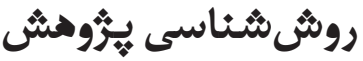


است. جامعه آمارى يثوهش شــامل فا مدرسه دخترانه و يسرانه مقطع ابتدايى جامع تعليمات اسـلامى بود. حجم جامعه آمارى شـامل • rV نفر بود كه با استفاده از جدول Krejcie \& Morgan دو حَـروه زن و مرد در جامعه آمارى، جهت انتخاب نمونـــهـ آمارى از روش نمونهَيرى تصادفى طبقهاى استفاده گرديد. بامنظور جمع آورى دادهها و اطلاعات مورد نياز در اين يروهش از دو يرسشنامه استاندارد و يك يرسشنامه محقق ساخته به شرح ذيل استفاده 
ا. يرسشنامه خوشبينى تحصيلى: جهت بررسى خوشبينى تحصيلى معلم از يرسشـنامه ل| آويهاى Beard, Hoy \& Woolfolk Hoy (2010) استفاده شد.




ياسخكويى برسشنامه نيز ه كَينهاى ليكرت از خيلى كم (1) تا خيلى زياد (ه)



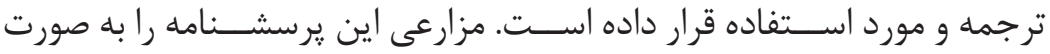

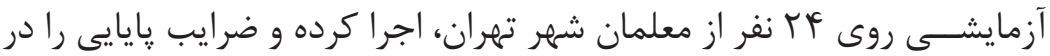



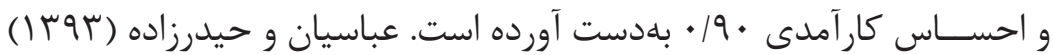









r. يرسشنامه هويت سازمانى: اين يرسشنامه توسط Mael \& Ashforth (1992)


ليكرت از بسيار مخالفم (1) تا بسيار موافقم (ه) مىباشد. اين يرسشنامه مؤلفه ندارد و با يك عامل كه همان هويت سـازمانى است اندازمخيرى مىشود. Mael Ashforth كردهاند. يايايى اين يرسشنامه در يزوهش نادى و مشايخى (99 (I)) با استفاده


استفاده از تحليل عاملى اكتشافى (با جرخش از نوع واريماكس) براساس مقادير








r. يرسشنامه تصوير سازمانى: براى بررسى تصوير سازمانى از يرسشنامه محقق ساخته استفاده شد. مبناى ساخت اين يرسشنامه مدل مفهومى تصوير سازمانى (2001) LeBlanc \& Nguyen

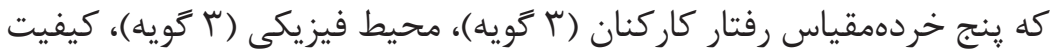

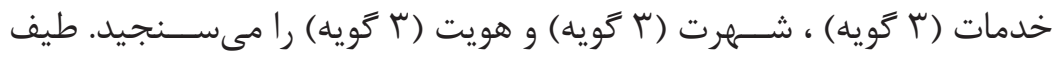

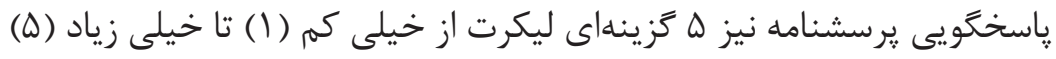
تنظيم شـــده بود. روايى اين برسشنامه با استفاده از روش روايى محتوايى تأييد شــد. براى بررسى يايايى يرسشنامه نيز از ضريب آلفاى كرونباخ استفاده شد و

$$
\text { ميزان آلفاى كرونباخ V9/ • محاسبه كرديد. }
$$

لازم به ذكر اســت يرسشـــامههاى فوق با توجه به زيســت بوم متفاوت مدارس

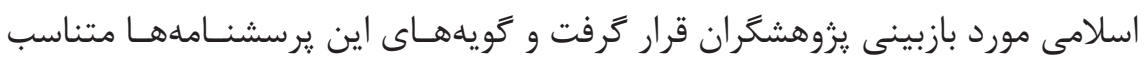
بــا مختصات فرهنخَـى، اجتماعى و ســاختارى اين مدارس تغييرات لازم داده شــــ.

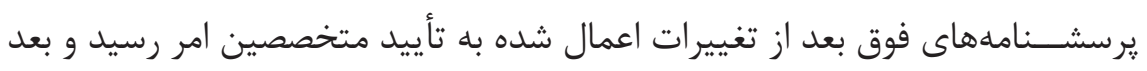

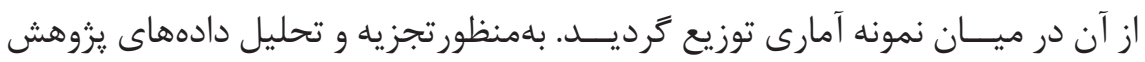

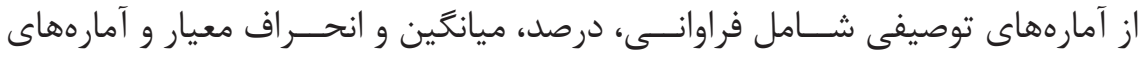
استنباطى شامل آزمون همبستخى ثيرسون و مدلسـازى معـادلات ساختارى استفاده شد. تجـزيه و تحـليل دادهها از طريق نرمافزارهاى SPSS نسخه آ و AMOS نسخه

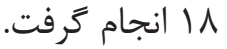

\section{باضْتهما}

يافته ياى مربوط به بخش جمعيتشناختى نمونه آمارى يزوهش نشان داد كه درصد ( س نفر) در زروه سنى F

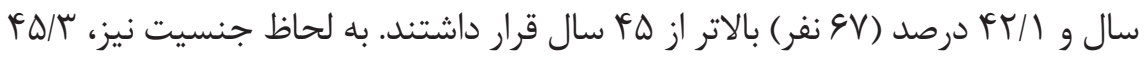

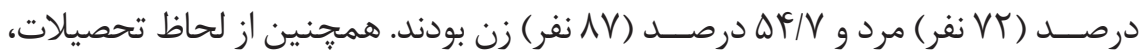
S/D درصد (T/ نفر) كاردانى، كارشناسى ارشد و r/ ا درصد (r نفر) دكترى بودند. 
قبل از اينكه به بررسى نقش ميانجى تصوير سازمانى در رابطه بين هويت سازمانى و

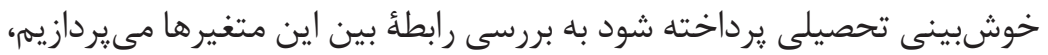



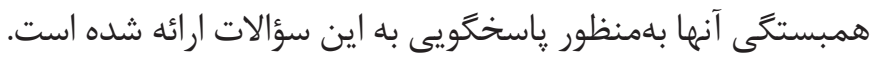

جدول ا. ميانكَين، انحراف معيار، ضريب همبستكى ييرسون وضريب يايايى متغيرهاى بروهش

\begin{tabular}{|c|c|c|c|c|c|c|}
\hline r & r & 1 & انحر اف معيار & ميانكين & متغيرها & \\
\hline & & $(\cdot / \lambda \mid)$ &.$|9|$ & $4 / 19$ & هويت سازمانى & 1 \\
\hline & $(\cdot / \vee 9)$ &.$/ 49 *$ & . & $4 / .9$ & تصوير سازمانى & $r$ \\
\hline$(\cdot / \wedge \Delta)$ & $\cdot|\Delta|^{* * *}$ & $\cdot / 19^{*}$ & $\cdot 149$ & r/^9 & خوشبينى تحصيلى & r \\
\hline
\end{tabular}

$* \mathrm{P}<\cdot / \cdot \Delta \quad * * \mathrm{P}<\cdot / \cdot 1$

همانطور كه در جدول ا مشــاهده مىشـود، ميانگين و انحراف معيار متغيرهاى هويت سازمانى، خوشبينى تحصيلى و تصوير سازمانى نشان داده شده است. همرجنين،

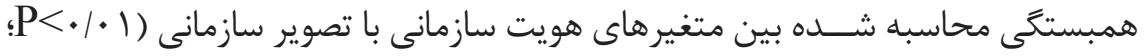

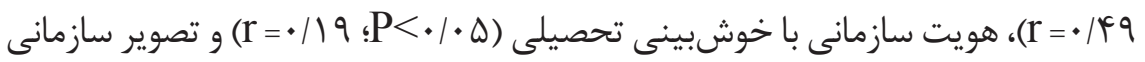

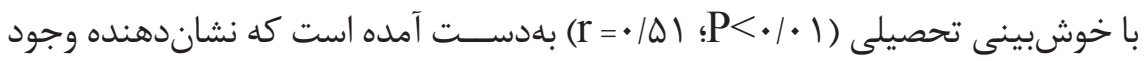

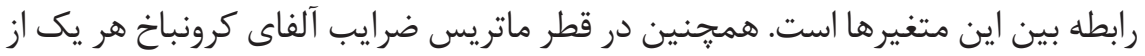

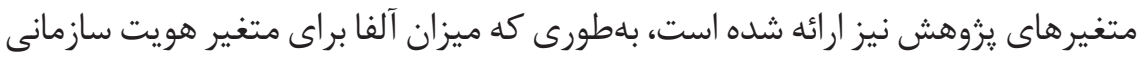

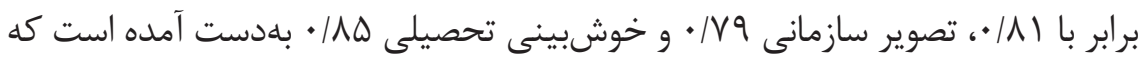

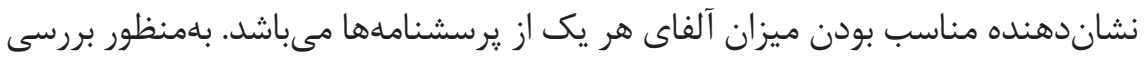

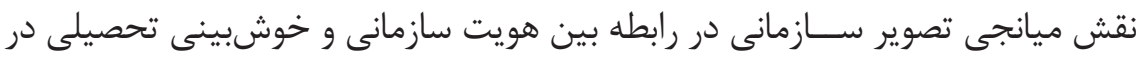

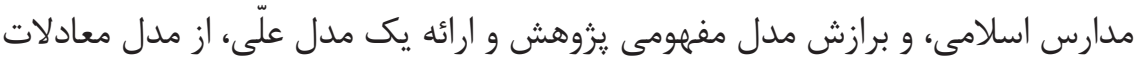


جدول r. شاخصهاى برازش مدل ساختارى نقش ميانجى تصوير سازمانى در رابطه بين هويت سازمانى و خوشبينى تحصيلى در مدارس اسلامى مئى

\begin{tabular}{|c|c|c|c|}
\hline دامنه قابل قبول & مقدار & معادل فارسى & علامت اختصارى \\
\hline$\cdot / 9 \cdot-1$ & . & شاخص برازش تطبيقى & CFI \\
\hline$\cdot 19 \cdot-1$ & $\cdot 19$ & شاخص توكر - لويس & TLI \\
\hline$\cdot 19 \cdot-1$ & .191 & شاخص برازش هنجار شده & NFI \\
\hline$\cdot 19 \cdot-1$ & .194 & شاخص نيكويى برازش & GFI \\
\hline$\cdot-\cdot \cdot \cdot 1$ & $\cdot 1 \cdot 9$ & ريشه ميانكين مربعات خطاى بر آورد & RMSEA \\
\hline يايينتر از ب & $r / F r$ & كاى اسكوئر بهنجار شده & CMIN/DF \\
\hline
\end{tabular}

همانطور كه در جدول r مشاهده مىشود، نتايج شاخصهاى برازش مدل ساختارى يزوهش ارائه شــده است. طبق نتايج بهدسـت آمده در اين جدول شاخصهاى برازش

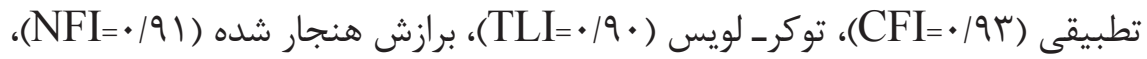

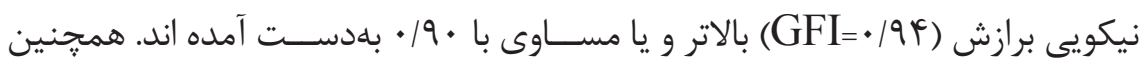
شاخص ريشه ميانگين مربعات خطاى بر آورد بر ابر با ؟ • • بلهدست آمده است كه كوجك-

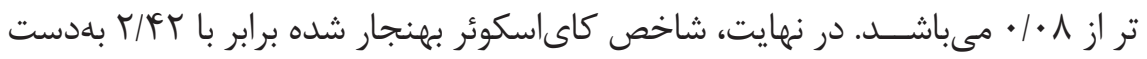

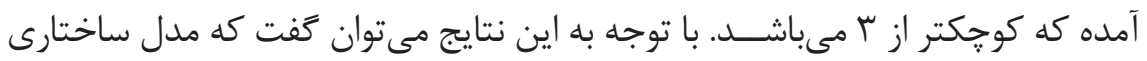


(نهايى) نقش ميانجى تصوير سازمانى در رابطه بين هويت سازمانى و خوشبينى تحصيلى در مدارس اسلامى نشان داده شده است. 
رابطه بين هويت سازمانى و خوش بينى تحصيلى بانقش ميانجى

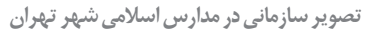

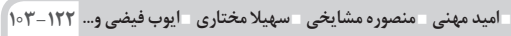

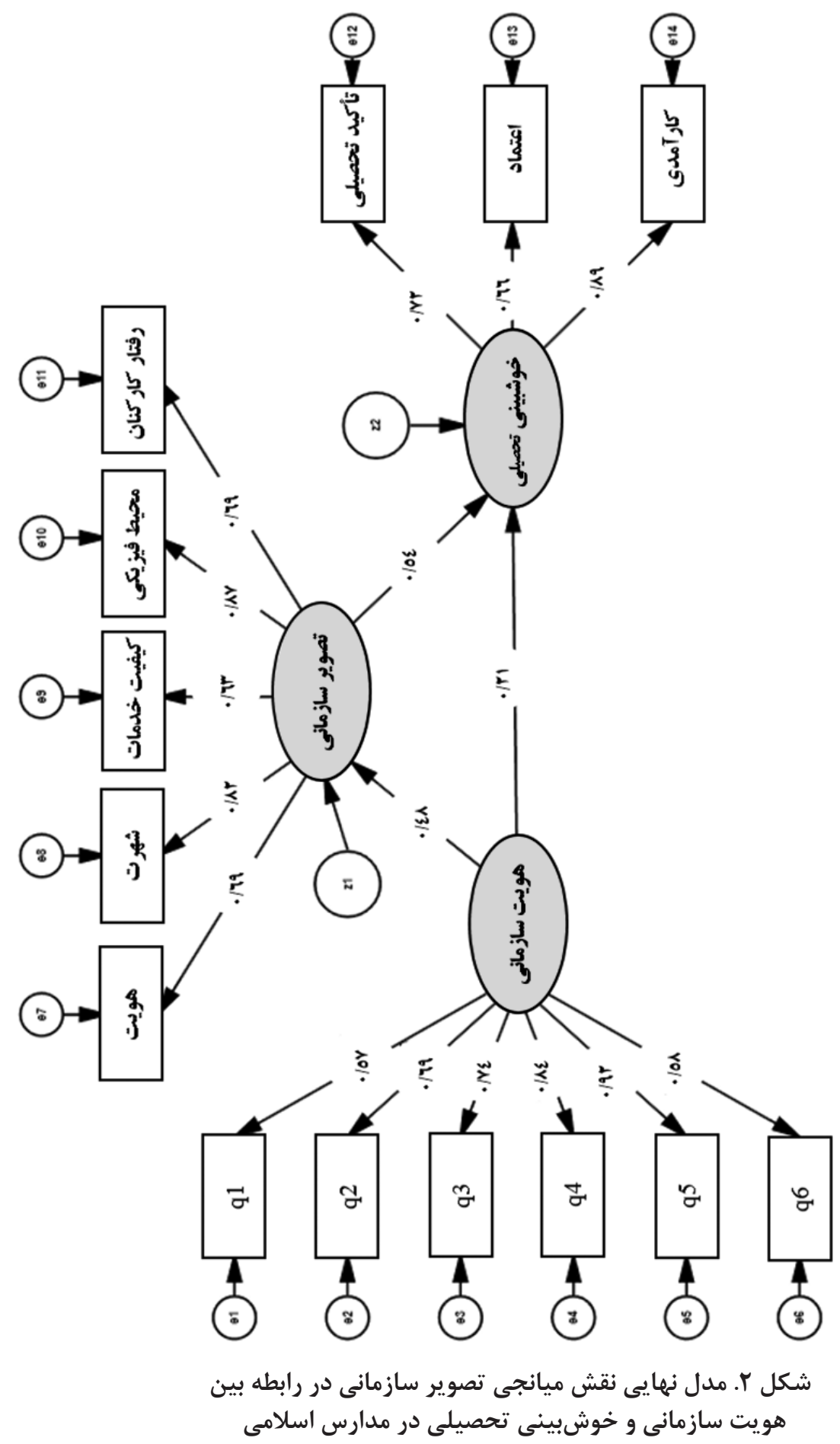


همانگَنه كه در شكل r و جدول r مشاهده مىشود، نتايج تحليل مسير حاكى از اين

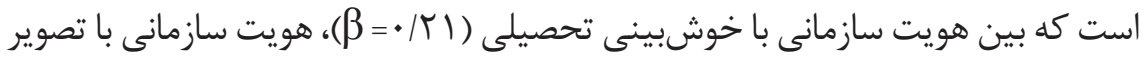


دارد (ه • • P<). همجنين، هويت سازمانى با ميانجيخرى تصوير سازمانى با خوشبينى

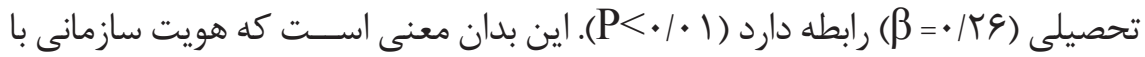
ميانجيخًرى تصوير سازمانى و به صورت غيرمستقيهم رابطه بالاترى با خوشبينى تحصيلى در مدارس اسلامى دارد تا به صورت مستقيه. در جدول س، ضرايب ومعنادارى متغيرهاى يزوهش در مدل ساختارى ارائه شده است.

جدول r. ضرايب مربوط به نقش ميانجى تصوير سازمانى در رابطه بين

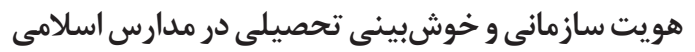

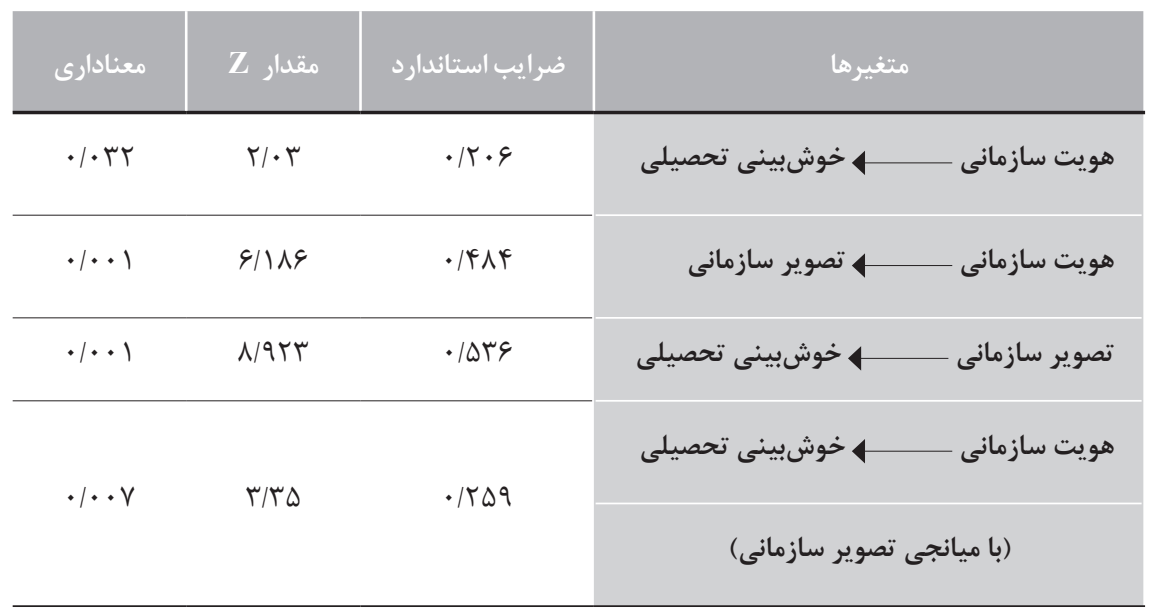

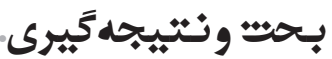

يزوهش حاضر با هدف نقش ميانجى تصوير سازمانى در رابطه بين هويت سازمانى و خوشبينى تحصيلى در مدارس اسلامى شهر تهران انجام شده است. يافتههاى يزوهش نشــان داد كه بين هويت ســازمانى با خوشبينى تحصيلى، هويت ســـازمانى با تصوير سازمانى و تصوير سازمانى با خوشبينى تحصيلى رابطه وجود دارد. همجنين نتايج نشان داد هويت ســازمانى با ميانجيخرى تصوير سازمانى با خوشبينى تحصيلى رابطه دارد. با توجه به نتايج يزوهش مىتوان به نقش و اهميت هويت ســازمانى بر مؤلفههاى كليدى 
خوشبينى تحصيلى و تصوير سـازمانى يى برد. در اين خصوص نتايج يزوهش يلماز و

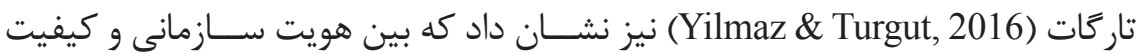

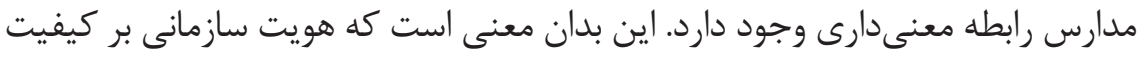

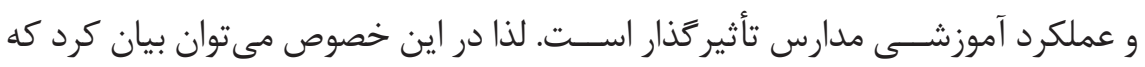

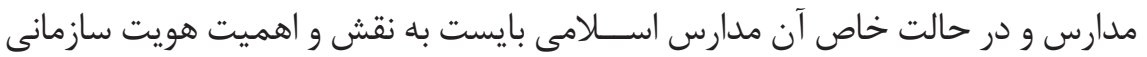

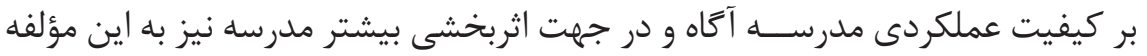
مهمم بيردازند. از اينرو ياسخى كه ذينفعان مدارس اسلامى به سؤال ما بهعنوان سازمان

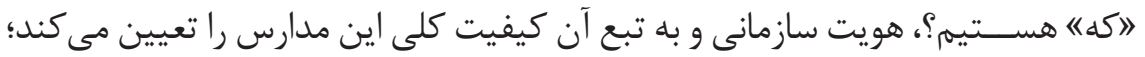

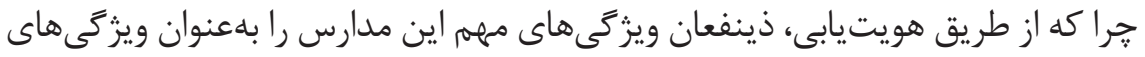
خود جذب مى كنند (اردلان، قنبرى و كريمى، هوب (1). مدارس اســلامى بايست هويتى

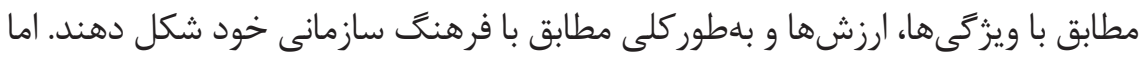

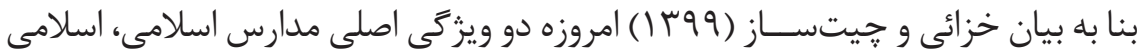

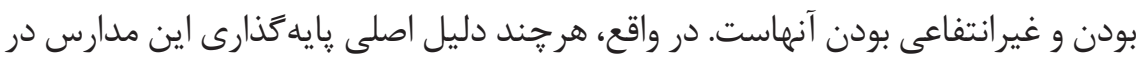

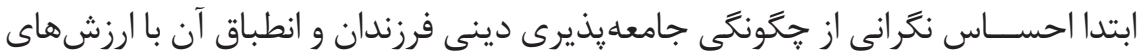
دينى بوده اســت، اما غيرانتفاعى بودن اين مدارس آنها را به بسترى براى شكل تركيرى يا تداوم حيات مرفهانه تبديل كرده است. از اينرو اهميت توجه به هويت سازمانى لامدرسه

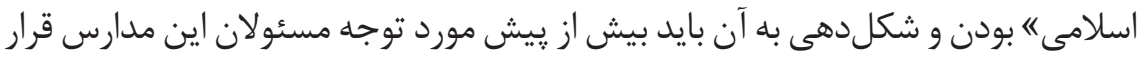

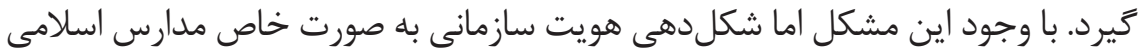
امكانيذير است، زيرا اين مدارس در اهداف خود، تعليمه و تربيت دينى و علمى را در كنار

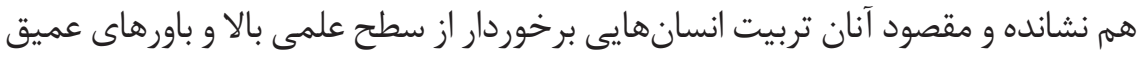

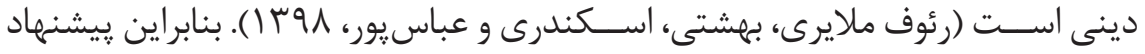

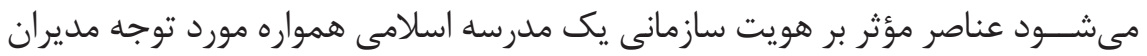

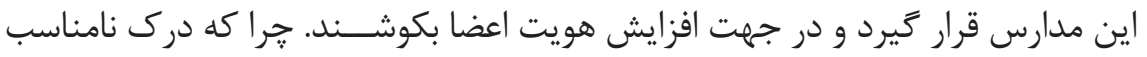

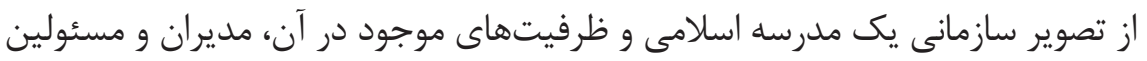

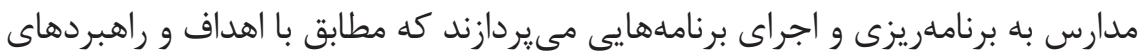

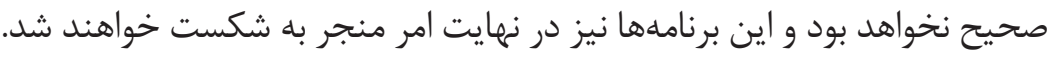

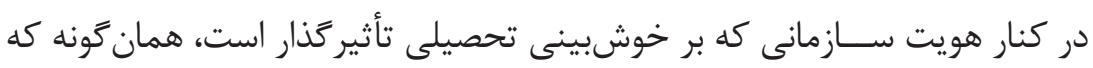


نتايج يزوهش نشان داد تصوير سازمانى نيز عاملى اثر گذار بر خوشبينى تحصيلى است و از اينرو اسـت كه بايد اتصوير سازمانى مدارس اسلامى" مورد توجه و تأكيد مديران و مســـئولان اين مدارس قرار گيرد. ايجاد اين تصوير براى مدارس اســلامى بسيار مهلهم است، جرا كه سازمانهايى كه جهت بقا و فعاليت به شدت وابسته به محيط اطراف خود

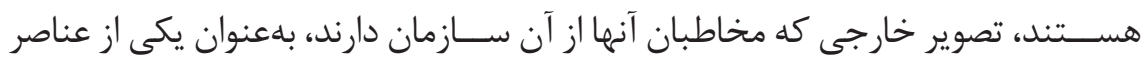
مهرم ارتباط با محيط خارج از ســازمان، مىتواند استراتزى خاصى را از سوى آن سازمان ايجاد كند (Hilman \& Siam, 2014). بنابراين لازم است مدارس اسلامى در زمينه ايجاد تصوير سازمانى مطلوب سرمايهگذارى كنند و با اتخاذ استراترىها و انجام يزوهشهايى در زمينه تصوير ســازمانى، ابعاد تأثير گذار آن را شناخته، وضعيت موجود خود را از نظر مخاطبان داخلى و خارجى مدرسه سنجيده و با آتاهى از دارايىهاى مشهود و نامشهود خود و مديريت تصوير ســازمانى، بتوانند تصوير ســازمانى مناسبى را در اذهان مردم و مخاطبين وجود آورند. از طرفى نيز با توجه به نقش مدارس اسلامى در توسعه فرهنگ اسلامى و تعالى جامعه، مديريت تصوير مدارس اسلامى نقش بسزايى در پيشبرد اهداف و كيفيت و اثربخشى اين مدارس نيز خواهد داشت. از اين رو برنامههاى مديران مدارس اســلامى در راستاى هويت سازمانى ادراك شـــده توسط اعضا مى تواند علاوه بر تأثيرات مستقيم بر خوشبينى تحصيلى، ارتقاى تصوير سازمانى آنان نيز مى رىود.

\section{تُشَّر و قدردانى}

از كليه مديران، معلمان و كاركنان مدارس اسلامى شهر تهران جهت همكارى براى انجام اين يزوهش تشكر و قدردانى مى كنيم. بى شك بدون همكارى ايشان انجام اين يثروهش ميسر نبود.. 


\section{منابع}

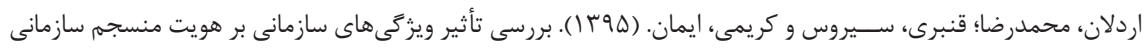

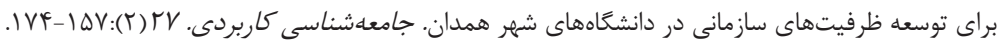

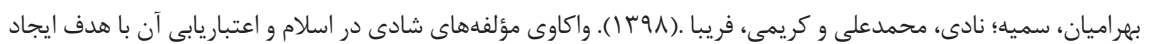

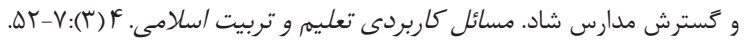

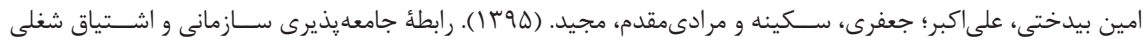

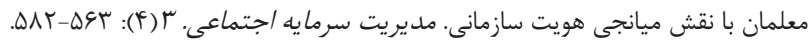

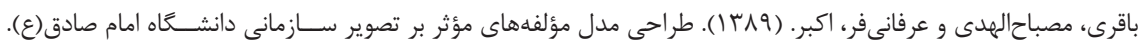

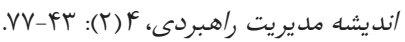

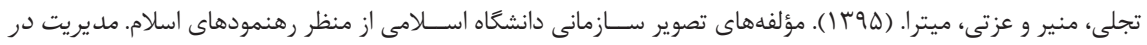

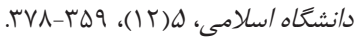

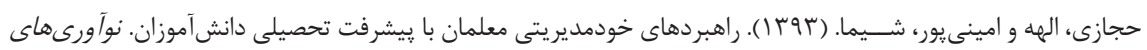

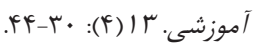

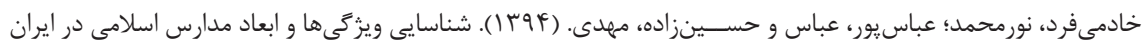

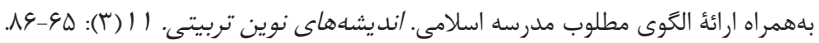
خزائى، طاهره و جيتســاز، غزاله. (

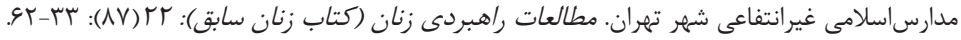

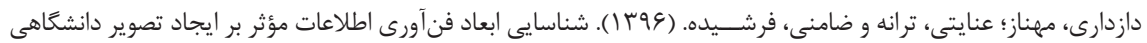

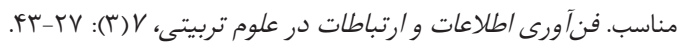

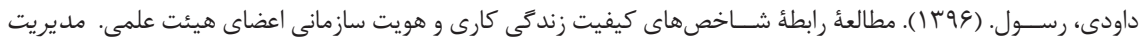

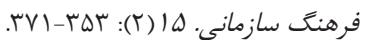

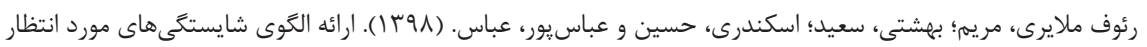

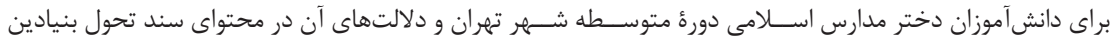

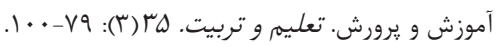

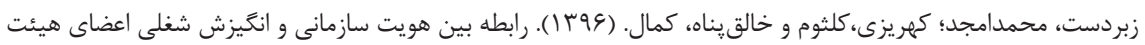

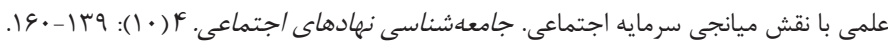

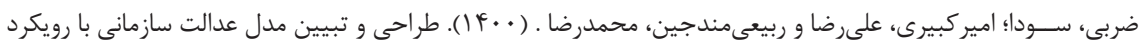

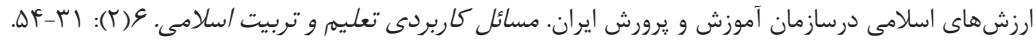

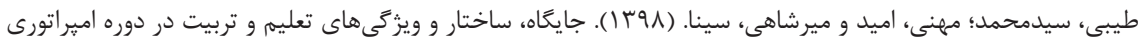

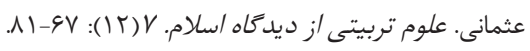

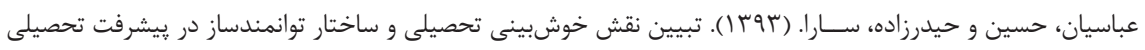

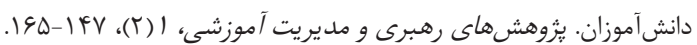

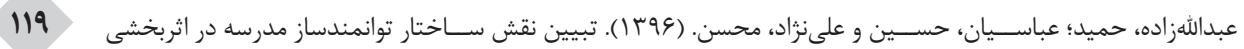
مدرسه با ميانجى كرى خوشبينى تحصيلى معلمان. مطالعات آموزشى و و آموزشكاهى.

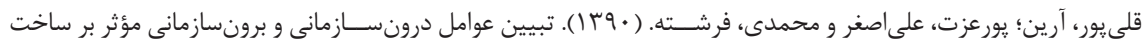




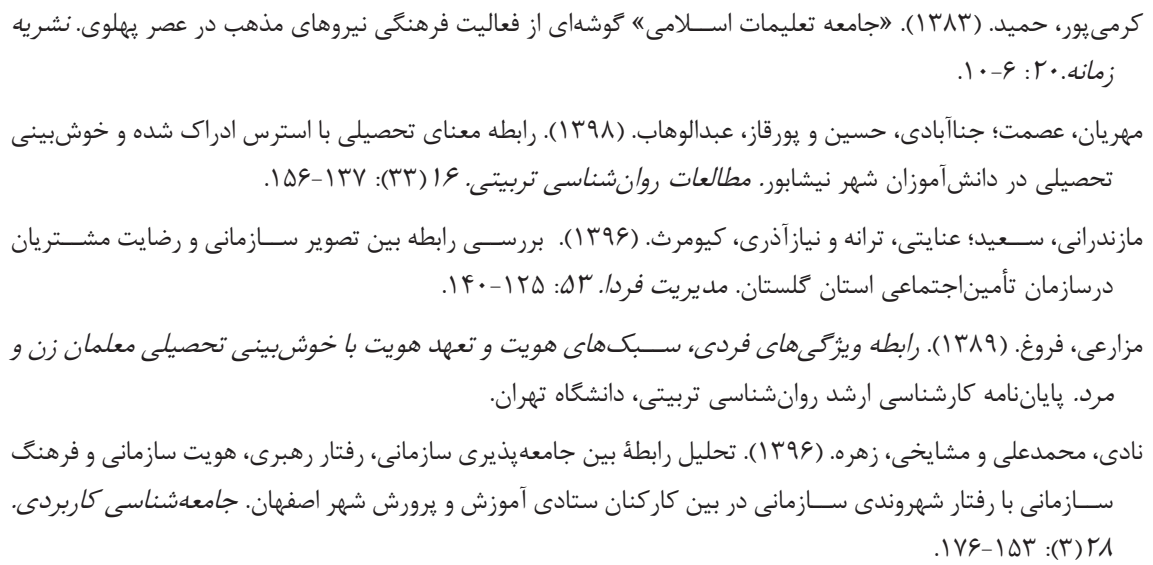

\section{REFERENCES}

Beard, K. S; Hoy, W. K; Woolfolk Hoy, A. W. (2010). Academic Optimism of Individual Teachers: Confirming a New Construct. Teaching and Teacher Education, 26(5), 11361147.

Boz, A; Saylik, A. (2021). The Impact of Enabling School Structure on Academic Optimism: Mediating Role of Altruistic Behaviors. International Journal of Educational Methodology, 7 (1):137-154.

Domurath, A; Patzelt, H; Liebl, A. (2020). Does Negative Feedback Impact New Ventures' Organizational Identity? The Role of Founding Teams' Human Capital and Feedback Source. Journal of Business Venturing. 35(3):1-22.

Eksi, H; Ozgenel, M; Demirci, M.E. (2020). The Mediator Role of Organizational Support in the Relationship Between Organizational Identity and Organizational Stress. International Journal of Educational Methodology, 6 (3):643-653.

Eren, A. (2012). Prospective Teachers' Future Time Perspective and Professional Plans About Teaching: The Mediating Role of Academic Optimism. Teaching and Teacher Education. 28 (1) : 111-123

Erdogmuş, I; Ergun, S. (2016). Understanding University Brand Loyalty: The Mediating Role of Attitudes Towards The Department and University. Procedia - Social and Behavioral Sciences. 229: 141-150.

Erstad, O; Mino, R; Rivera-Vargas, P. (2021). Educational Practices to Transform and Connect Schools and Communities. Comunicar: Media Education Research Journal, 29 (66) :9-19.

Heinberg, M; Ozkaya, E; Taube, M. (2018). Do Corporate Image and Reputation Drive Brand Equity in India and China? - Similarities and Differences. Journal of Business Research. 86: 259-268.

Hilman, H; Siam, M. (2014). The Influence of Organizational Structure and Organization 
Culture on the Organizational Performance of Higher Educational Institutions: The Moderating Role of Strategy Communication. Asian Social Science, 10(13): 142-154.

Hsieh, C.C; Yen, H.C; Kuan, L.Y. (2014). The Relationship Among Principals' Technology Leadership, Teaching Innovation, and Students' Academic Optimism in Elementary Schools. International Association for Development of the Information Society, Paper presented at the International Conferences on Education Technologies (ICEduTech) and Sustainability, Technology and Education (STE) (New Tapei City, Taiwan, Dec 10-12, 2014)

Krejcie, R. V; Morgan, D. W. (1970). Determining Sample Size For Research Activities. Educational and Psychological Measurement, 30(3), 607-610.

LeBlanc, G; Nguyen, N. (1996). Cues Used by Customers Evaluating Corporate Image in Service Firms, An Empirical Study in Financial Institution. International Journal of Service Industry Management. 7(2). 44-56.

Levin, J.S; Lopez Damian, A.I; Martin, M.C; Vazquez, E.M. (2018). New Universities' Organizational Identities through Presidential Lenses. Canadian Journal of Higher Education, 48 (2):20-38.

Kucuksuleymanoglu, R. (2015) Organizational Image Perceptions of Higher Education Students. Educational Research and Reviews, 10(20): 2667-2673.

Mael, F; Ashforth B.E. (1992). Alumni and Their Alma Mater: A Partial Test of The Reformulated Model of Organizational Identification. Journal of Organizational Behavior, 13, 103-123.

Makvandi, A; Naderi, F; Makvandi, B; Pasha, R; Ehteshamzadeh, P. (2018). Academic Optimism and Organizational Citizenship Behaviour amongst Secondary School Teachers. International Journal of Emotional Education, 10 (1) :164-166.

Misbah, M; Sulaeman, S; Bakhri, S. (2019). Role of Leadership in Organizational Change: A Case Study at Attaqwa Putra Islamic Boarding School Bekasi - Indonesia. Asian Journal of Contemporary Education, 3 (1): 72-84.

Moghtadaie, L; Hoveida, R. (2015). Relationship Between Academic Optimism and Classroom Management Styles of Teachers--Case Study: Elementary School Teachers in Isfahan. International Education Studies, 8 (11) :184-192.

Nguyen, N; Yu, X; Melewar, T.C; Hemsley-Brown, J. (2016) Brand Ambidexterity and Commitment in Higher Education: An Exploratory Study. Journal of Business Research. $69(8): 3105-3112$.

Rauschnabel, P; Krey, N; Babin, B; Ivens, B. S. (2016). Brand management in higher education: The University Brand Personality Scale. Journal of Business Research. 69 (8) :3077-3086.

Sezgin, F; Erdogan, O. (2015). Academic Optimism, Hope and Zest for Work as Predictors of Teacher Self-Efficacy and Perceived Success. Educational Sciences: Theory and Practice. 15 (1) : 7-19. 
Susylowati, E; Sumarlam, S; Abdullah, W; Marmanto, S. (2019). Code Switching by Female Students of Islamic School in Daily Communication: Modern Islamic Boarding School. Arab World English Journal, 10 (2): 102-114.

Syed Alwi, S. F; Kitchen, P. (2014). Business Schools Brand image: A Design Perspective. Journal of Business Research, 67 (11): 2324-2336.

Utami, P.P; Vioreza, N. (2021). Teacher Work Productivity in Senior High School. International Journal of Instruction, 14 (1):599-614.

Valitov, S. M. (2014) University Brand as a Modern Way of Winning Competitive Advantage. Procedia - Social and Behavioral Sciences. 152: 295-299.

Wu, J.H; Sheu, T.M. (2015). How to Improve Academic Optimism? an Inquiry From The Perspective of School Resource and Investment. Asia Pacific Education Review, 16 (4) :663-674.

Yilmaz, E; Turgut, M. (2016). A Study on Teachers' Perceptions of Organizational Identity in Terms of Learning School. International Journal of Contemporary Educational Research, 3 (1):25-33. 